\title{
How Does Financial Performance Effect Environmental Investment and How Do Foreign Ownership Moderate It?
}

\author{
Yuztitya Asmaranti ${ }^{1}$, Lindrianasari $^{2}$, Kiagus Andi $^{3}$, Alvira Putri Chairunnisa ${ }^{4}$ \\ \{yuztitya@yahoo.com ${ }^{1}$, sari_170870@yahoo.com ${ }^{2}$, kgs_andi@yahoo.co.id ${ }^{3}$, chairunnisavir@gmail.com ${ }^{4}$ \}
}

Faculty of Economics and Business, University of Lampung, Jl. Sumantri Brojonegoro, Bandar Lampung, Indonesia ${ }^{1}$, Faculty of Economics and Business, University of Lampung, Jl. Sumantri Brojonegoro, Bandar Lampung, Indonesia ${ }^{2}$, Faculty of Economics and Business, University of Lampung, Jl. Sumantri Brojonegoro, Bandar Lampung, Indonesia ${ }^{3}$, Faculty of Economics and Business, University of Lampung, Jl. Sumantri Brojonegoro, Bandar Lampung, Indonesia ${ }^{4}$

\begin{abstract}
The purpose of this study is to examine whether financial performance affects environmental investment. Furthermore, this study examines whether foreign ownership moderates the financial performance of the environmental investment. This study tries to contribute to the response of mining companies in Indonesia in preserving the environment by investing in the environment. The method used in this study is multiple linear regression. The number of samples of this study is 195, which are mining companies in Indonesia published in 2014-2018. The results of this study indicate that mining companies in Indonesia have a relatively low response in making environmental investments. However, this study indicates that financial performance affects environmental investment and foreign ownership moderates the financial performance of the environmental investment. The implication of this research is the important role of the government to encourage mining companies in Indonesia to invest in the environment.
\end{abstract}

Keywords: Environmental Investment, Financial Performance, Foreign Ownership.

\section{Introduction}

In the last few years, the Indonesian people have been shocked by the circulation of documentary films related to the negative impacts of mining by several companies in Indonesia. It has been carried out by these companies are: ex-excavation is not reclaimed, causing water and air pollution as well as many casualties, the emergence of fly ash and bottom ash from the coal-burning residue, and damage to coral reefs. Companies in carrying out expansion will expect economic benefits from their operations. On the other hand, if the expansion is carried out sustainably, it will result in environmental damage and harm the environment and society.

Previous research has discussed the importance of environmental awareness to protect the environment and society. Manufacturing companies make environmental awareness a mainstream issue so that companies encourage management to develop policies and apply new technology as a form of environmental concern[1]. The motivation of companies to undertake environmental investment is to form a corporate image, regulatory preemption, reduce production costs, and reduce compliance costs with existing regulations[2]. Environmental investment is a form of direct or indirect payment to various stakeholders[3]. Furthermore, they stated that it was revealed that the costs of preventing pollution, recycling efforts, using alternative fuels, are indirect payments to the wider community.

The companies that have higher profits have a positive effect on environmental investment[4]. Furthermore, it is explained that high profits will be a consideration for investing in the environment. However, other researchers state that environmental performance and company performance are not related[5].

On the other hand, the ownership structure influences the relationship between financial performance and environmental investment. Firm size is a factor related to environmental investment[6]. Furthermore, different company sizes will generate different profits. The large companies have more resources to invest so that the larger the size of the company, the greater the investment, including investment in the environmental sector[7]. 
Investors (both institutional investors and foreign investors) can increase company awareness of the importance of protecting the environment. Foreign investors will be more responsive to issues related to the environment.[8]found the influence of foreign ownership on environmental investment.

Not many accounting studies have discussed environmental investment. This study will discuss whether financial performance affects environmental investment. This study will also examine whether foreign ownership will moderate the relationship between financial performance and environmental investment.

\section{Literature Review}

Legitimacy theory focuses on the interactions between companies and communities. Legitimacy is defined as a general perception or assumption that the actions of an entity are desirable, appropriate, or appropriate in some socially constructed system of norms, values, beliefs, and definitions [9]. [10], legitimacy theory believes in the idea that there is a "social contract" between an organization and the environment in which the organization operates. The concept of "social contract" is used to show people's expectations about the way an organization should carry out its activities. Legitimacy can be obtained when there is a match between the existence of a company that is suitable and does not interfere with the existence of the existing value system in society and the environment[11].

Stakeholder theory suggests that an identified group of people or individuals can influence company activities or can be influenced by company activities[12]. According to[13], stakeholders can be divided into two based on their characteristics, namely primary stakeholders and secondary stakeholders. Primary stakeholders are a person or group without which the company cannot survive a going concern, including shareholders and investors, employees, consumers, and suppliers, together with those defined as public stakeholder groups, namely: government and communities Secondary stakeholder groups are defined as those who influence, or are influenced by the company, but are not related to transactions with the company and are not essential for their sustainability. The primary stakeholder is the most influential stakeholder for the continuity of the company because it has a high enough power to the availability of company resources.

Companies that make environmental investments can respond to stakeholder concerns and will have a social responsibility that can build a good reputation[14]. The environmental investment has a positive effect on company performance in the long run[7].

The greater the foreign ownership in the company, the greater the pressure on company management to disclose social responsibility[8]. This can encourage companies to invest in the environment as a responsibility to shareholders. This is because foreign investors are parties who are considered very concerned about environmental issues and problems.[15]found that an increase in environmental performance was influenced by foreign investment. SDGs Index (Sustainable Development Goals Index) describes the state's achievement conditions for the success of solving world problems. Based on the SDGs Index, European countries have a higher level of awareness of the environment.

\section{$\mathrm{Ha}_{1}$ : Financial performance affect positively environmental investment \\ Ha2: Foreign ownership moderates the effect of financial performance with environmental investment}

\section{Methodology and Data Analysis}

\subsection{Research Sample}

The population in this study are mining companies listed on the Indonesia Stock Exchange in 2014-2018. Based on this population, the sample will be determined as the object of research. The sample selection technique used was purposive sampling, with the criteria being issuers in the mining sector. The number of samples in this study is 195 data. 


\subsection{Research Variable}

The dependent variable in this study is an environmental investment. Environmental investment is a preventive action in environmental management to reduce the negative impact of company activities. Environmental investment is calculated by the formula:

$$
\text { Environmental Investment }=\frac{\text { Total environmental ascets }}{\text { Total assets }}
$$

The independent variable in this study is sales growth as proxy of financial performance. Sales growth is an indicator of a company's demand and competitiveness in the industry. Sales growth is calculated using the formula:

$$
\text { Sales Growth }=\frac{\text { Sales }_{t}-\text { Sales }_{t-1}}{\text { Sales }_{t-1}}
$$

Foreign ownership is a moderating variable in this study. Foreign ownership in the ownership structure is believed by some researchers to be able to influence the running of the company which ultimately affects financial performance to maximize firm value. Foreign ownership is formulated as follows:

$$
\text { Foreign Ownership }=\frac{\text { Foreign ownership shares }}{\text { Total shares }}
$$

\subsection{Hypothesis Testing}

The method of testing the hypothesis in this study uses multiple linear regression and moderation testing using SPSS. The level of significance used is $\alpha=5 \%$.

\section{Research Results and Discussion}

Table 1 . The result of descriptive statistics

\begin{tabular}{lrrrr}
\hline & Min & \multicolumn{1}{c}{ Max } & Mean & Std Deviation \\
\hline Financial performance & -0.9593 & 63.0204 & 0.918369 & 5.7757 \\
Foreign ownership & 0.9897 & 0.0000 & 0.288895 & 0.9897 \\
Environmental investment & 0.5231 & 0.0000 & 0.056782 & 0.5231 \\
\hline
\end{tabular}

Based on the results of descriptive statistical tests on table 1. the value of the environmental investment is relatively small, however, sales growth as proxy of financial performance can maximize and make the company more efficient in its environmental investment. This indicates that the company's production activities can support the sustainability of the company's environmental investment in the future. That way the company gets legitimacy by the community by producing environmentally friendly products.

Table 1. shows that the average sales growth of $91.4 \%$ is a relatively high value, while the company invests only $2.4 \%$ of its assets in the environment. It proves that companies that have good financial performance do not necessarily invest in the environment. Companies that have good financial performance will have qualified resources in making environmental investments. The higher the sales growth, the higher the company's profit. Therefore the company will invest in the environmental sector

\begin{tabular}{|c|c|c|}
\hline Hypothesis & $\mathrm{t}$ & Sig \\
\hline $\begin{array}{l}\mathrm{Ha}_{1} \text { : Financial performance affect environmental } \\
\text { investment }\end{array}$ & 2,831 & 0.05 \\
\hline $\begin{array}{l}\mathrm{Ha}_{2} \text { : Foreign ownership moderates the effect of } \\
\text { financial performance with the environmental } \\
\text { investment }\end{array}$ & $-2,023$ & 0.044 \\
\hline
\end{tabular}
because it increases the company's legitimacy.

Table 2. The result of hypothesis testing and moderation 
Based on the result of hypothesis testing on table 2. financial performance affect positively environmental investment. Environmental investment can be linked to environmental assets. There is a close relationship between environmental investment and environmental assets because the costs incurred by the company in the context of environmental management efforts which can have an impact on the company's future sustainability in environmental accounting records must be disclosed in the form of assets. Environmental investments that are included in the category of environmental assets are usually assets that are believed to have economic value and have an impact on income or sales that will be obtained by the company in the future.

Statistical testing on table 2. also proves that foreign ownership is a pure moderator between the influence of financial performance and environmental investment.[15]stated that foreign investors in the mining sector are trying to apply the latest technology and environmental management. For reasons of an internal nature, foreign-owned companies may be cleaner than domestically-owned companies incorporate management practices[16].Foreign parties will be more interested in companies with a good reputation in the social sector because western countries are countries that are very concerned about the environment which includes social issues. The awareness of environmental concerns by foreign parties is evidenced by the number of companies that have conducted environmental campaigns as their concern for the environment.

\section{Conclusion}

In this study, we examine the effect of financial performance on environmental investment and how foreign ownership moderates it. Our findings indicate that sales growth as proxy of financial performance affects environmental investment. However, environmental investment has a relatively low, so the government should pay more attention to companies. Furthermore, the findings of this study indicate that foreign ownership becomes a pure moderator for company performance and environmental investment. Foreign parties will be more interested in companies with a good reputation in the environmental sector because foreign countries, for example in Europe and America, are countries that are very concerned about the environment. This is as stated in the SDGs Index (Sustainable Development Goals Index) in 2018.

Investments in the environmental sector are starting to get more attention from the public. This environmental investment can reflect the company's performance in managing the environment and indirectly the community will give appreciation and legitimacy to the company. This shows that good environmental performance is a reflection of the quality and quantity of environmental investments made by companies[17].

The practical contributions of this research explain that companies in Indonesia have invested in environmentally friendly assets despite their relatively low value. As for the policy contribution, it is hoped that there will be clear regulations so that the company's operational activities can preserve the environment and have a positive impact on the surrounding community.

\section{Implications and Suggestions for Future Research}

This research implies the importance of government intervention to force companies to preserve the environment in carrying out mining operations. The government is also expected to have the right regulations so that foreign investors are interested in investing in Indonesia. Further researchers are advised to look at the aspect of market performance as a form of response from investors in assessing company performance in environmental management. 


\section{Acknowledgments}

This research can be completed with funding from University of Lampung. We thank you for the support.

\section{References}

[1] R. D. KLASSEN and S. VACHON, "Collaboration and Evaluation in the Supply Chain: the Impact on Plant-Level Environmental Investment,” Prod. Oper. Manag., vol. 12, no. 3, pp. 336-352, 2009, doi: 10.1111/j.1937-5956.2003.tb00207.x.

[2] J. W. Maxwell and C. S. Decker, "Voluntary environmental investment and responsive regulation," Environ. Resour. Econ., vol. 33, no. 4, pp. 425-439, 2006, doi: 10.1007/s10640-005-4992-z.

[3] M. T. J. Rakotomavo, "Corporate investment in social responsibility versus dividends?," Soc. Responsib. J., vol. 8, no. 2, pp. 199-207, 2012, doi: 10.1108/17471111211234833.

[4] A. A. Ullmann, "Data in Search of a Theory: A Critical Examination of the Relationships among Social Performance, Social Disclosure, and Economic Performance of U. S. Firms," Acad. Manag. Rev., vol. 10, no. 3, p. 540, 1985, doi: 10.2307/258135.

[5] J. L. F. Sánchez and L. L. Sotorrío, "The creation of value through corporate reputation," J. Bus. Ethics, vol. 76, no. 3, pp. 335-346, 2007, doi: 10.1007/s10551-006-9285-0.

[6] S. L. Hart, G. Ahuja, and A. Arbor, "<Orsato-2006-Competitive Environmental Strategi.pdf>," vol. 5, no. 1996, pp. 30-37, 2000, doi: 10.1002/(SICI)1099-0836(199603)5:1<30::AID-BSE38>3.3.CO;2-H.

[7] E. Nakamura, "Does Environmental Investment Really Contribute to Firm Performance? An Empirical Analysis Using Japanese Firms,” Eurasian Bus. Rev., vol. 1, no. 2, pp. 91-111, 2011, doi: 10.14208/BF03353800.

[8] I. Chariri, A \& Ghozali, Teori Akuntansi. Semarang: Badan Penerbit Universitas Diponegoro, 2007.

[9] M. C. SUCHMAN, "MANAGING LEGITIMACY: STRATEGIC AND INSTITUTIONAL APPROACHES," Acad. o/ Manag. Rev., vol. 20, no. 3, pp. 571-610, 1995, doi: https://doi.org/10.5465/amr.1995.9508080331.

[10] C. Deegan, "Organizational legitimacy as a motive for sustainability reporting," Sustain. Account. Account., pp. 127-149, 2010, doi: 10.4324/9780203815281.

[11] C. Deegan, M. Rankin, and J. Tobin, An examination of the corporate social and environmental disclosures of BHP from 1983-1997: A test of legitimacy theory, vol. 15, no. 3. 2002.

[12] R. E. Freeman and L. R. David, "Stockholders and Stakeholders: A New Perspective on Corporate Governance," Calif. Manage. Rev., vol. 25, no. 3, pp. 88-106, 1983, doi: 10.2307/41165018.

[13] M. E. Clarkson, "a Stakeholder Framework for Analyzing and Evaluating Corporate Social Performance.," Acad. Manag. Rev., vol. 20, no. 1, pp. 92-117, 1995, doi: 10.5465/amr.1995.9503271994.

[14] B. W. Husted and J. De Jesus Salazar, "Taking friedman seriously: Maximizing profits and social performance," J. Manag. Stud., vol. 43, no. 1, pp. 75-91, 2006, doi: 10.1111/j.1467-6486.2006.00583.x.

[15] N. Borregaard and A. Dufey, "Environmental effects of foreign investment versus domestic investment in the mining sector in Latin America," Conf. Foreign Direct Invest. Environ. Lessons to be Learn. from Min. Sect. OECD Glob. Forum Int. Investment, Paris, no. February, pp. 3341091-3341096, 2002.

[16] M. A. Cole, R. J. R. Elliott, and E. Strobl, "The environmental performance of firms: The role of foreign ownership, training, and experience," Ecol. Econ., vol. 65, no. 3, pp. 538-546, 2008, doi: 10.1016/j.ecolecon.2007.07.025.

[17] P. Clarkson, Y. Li, G. D. Richardson, and F. P. Vasvari, "Does it Really Pay to Be Green? Determinants and Consequences of Proactive Environmental Strategies," SSRN Electron. J., 2011, doi: 10.2139/ssrn.955890. 